\title{
THE USE OF AUTHENTIC MATERIALS TO ADVANCE STUDENTS' COMMUNICATIVE COMPETENCES IN EFL CLASS
}

\author{
Rosyida Ekawati \\ English Study Program, University of Trunojoyo Madura \\ e-mail: idasunyigono@gmail.com
}

\begin{abstract}
In EFL settings, in mastering English Language students do not merely study on rule of the language but more on communicative purposes. So, they need more practices using English in the classroom and a teacher has to lead students to always practice English. From the four competences, i.e. linguistic, sociolinguistic, discourse, and strategic competences, they must be integrated to lead students achieve the communicative competence. Authentic materials are not created specifically to be used in the classroom and the use of authentic materials that can be obtained from the materials in surrounding daily life can reinforce the direct relationship between the language classroom and the outside world for the students. It helps students involve in the real language as long as teachers provide them with educational support.
\end{abstract}

Keywords: Authentic Materials, Communicative Competence, EFL 


\section{INTRODUCTION}

Teaching and learning in the framework of English as Foreign Language (EFL) should help students to be competent to use of the language. EFL students have also to be able to develop their language skills that are unfamiliar with their native language (Celce-Murcia, 2005). Furthermore, EFL students in mastering English Language are not merely studying rule of the language but more on communicative purposes. So, EFL students need lots of practices using English in the classroom and a teacher has to lead students to always practice English. Teachers never lead the students to believe that English is a set of rules and words to memorize (Oxford University Press ELT, 2011).

In connection with these objectives, Widdowson (1990) stated that the communicative approach is one of the approaches that can be used and has clearly substituted more traditional methods in the teaching of English as Foreign Language, namely the so-called Grammar-Translation method. Moreover, Oxford (2001) cited by Shomoossi and Ketabi (2007) stated some teaching practices such as multiple intelligences, cooperative learning, task-based learning, and content-based learning try to lead to authentic interaction in classroom.

Beside the use of method or approach in EFL teaching, one of the most essential tools in EFL teaching and learning is the materials used during the classroom activities (Pietila, 2009). The materials can have a significant effect on the language learners' motivation, learning process and desire to learn more. In other words, teaching materials are the key component in most language class. Whether the teacher uses a textbook, institutionally prepared materials, or his or her own materials, instructional materials generally serve as the basis for much of language input learners receive and the language practice that occurs in the classroom.

Then, the materials can also be created from the learners' point of view since they are the ones who get benefit from the materials. One of the materials supported the benefit of the students is authentic materials. Interest in authentic materials has a history as long as 1890s and it is believed that natural texts do justice to every feature of the language, while artificial materials include repetition of certain grammatical constructions, certain elements of the vocabulary, certain combinations of words to the almost total exclusion of others which are equally, or perhaps even more essential (Gilmore, 2004). Moreover, Richards (2001) referring to the facilitating role of authentic materials believes that communication which takes place in the class must simulate as much as possible the communication observable in the real world.

The reappearance of authenticity according to Gilmore (2004) refers back to the discussion raised by Chomsky (1965) and Hymes (1972) remarked that communicative competence does not only comprise the knowledge of the language but the need for contextualized communication. The climax of this view was seen in communicative language teaching. Moss (2005) also stated that with Communicative Language Teaching, instructional emphasis shifted from grammar translation, memorization of dialogues, and drills and practice of structural patterns to using language in real-life contexts for meaningful purposes that demands authentic use of language and materials as well, which means people interacting with other people.

Moreover, how to make students' interact and speak or in other words how to advance students' communicative competences are beneficial seemingly rely on the approach or method and as well materials the teachers use during classroom's activities. 


\section{COMMUNICATIVE COMPETENCE}

The idea of communicative competence first appears as a critic of Chomsky's linguistic theory (Acar, 2005). He states linguistic theory is concerned primarily with an ideal speaker-hearer, in a completely homogeneous speech community, who knows its language perfectly and is unaffected by such grammatically irrelevant conditions as memory limitations, distractions, shifts of attention and interest, errors (random or characteristic) in applying his knowledge of the language in actual performance.

Communicative competence is seen as an aspect of what from another angle may be called the ethnography of symbolic forms, the study of the variety of genres, narration, dance, drama, song, instrumental music, visual art, that interrelate with speech in the communicative life of a society and in terms of which the relative importance and meaning of speech and language must be assessed (Hymes, 1972). Communicative competence is made up of four competence areas: linguistic, sociolinguistic, discourse, and strategic.

Celce-Murcia (1995) elaborated Canale \& Swain's (1980) idea on communicative competence. It is the comprehensive model of communicative competence which was intended to serve both instructional and assessment purposes. This model posited four components of communicative competences. They are linguistic, sociolinguistic, discourse, and strategic competences.

Linguistic competence is knowing how to use the grammar, syntax, and vocabulary of a language. Linguistic competence asks: What words do I use? How do I put them into phrases and sentences?

Sociolinguistic competence is knowing how to use and respond to language appropriately, given the setting, the topic, and the relationships among the people communicating. Sociolinguistic competence asks: Which words and phrases fit this setting and this topic? How can I express a specific attitude (courtesy, authority, friendliness, respect) when I need to? How do I know what attitude another person is expressing?

Discourse competence is knowing how to interpret the larger context and how to construct longer stretches of language so that the parts make up a coherent whole. Discourse competence asks: How are words, phrases and sentences put together to create conversations, speeches, email messages, newspaper articles?

Strategic competence is knowing how to recognize and repair communication breakdowns, how to work around gaps in one's knowledge of the language, and how to learn more about the language and in the context. Strategic competence asks: How do I know when I've misunderstood or when someone has misunderstood me? What do I say then? How can I express my ideas if I don't know the name of something or the right verb form to use?

These competences do not need to be taught in separate activities, but it can be conducted in one activity with a certain topic. During the interaction in the classroom, students are encouraged to acquire and find strategies to advance these kinds of competences. The teacher facilitates and advocates the students whenever they got stuck during the classroom activities. 


\section{AUTHENTIC MATERIALS}

Harmer (1991) defined authentic texts as materials which are designed for native speakers; they are real texts; designed not for language students, but for the speakers of the language. Furthermore, Nunan (1999) elaborated that authentic materials as spoken or written language data that has been produced in the course of genuine communication, and not specifically written for purposes of language teaching. In short, authentic materials are materials that we can use with the students in the classroom and that have not been changed in any way for ESL students (Sanderson, 1999). So, authentic materials are not created specifically to be used in the classroom.

\section{SOURCES OF AUTHENTIC MATERIALS}

There are a lot of sources of authentic materials for EFL classroom activities. According to Gebhard (1996), authentic materials can be classified into three categories.

1. Authentic listening/viewing materials: TV commercials, quiz shows, cartoons, news clips, comedy shows, movies, soap operas, professionally audio-taped short stories and novels, radio ads, songs, documentaries, and sales pitches.

2. Authentic visual materials: slides, photographs, paintings, children's artwork, stickfigure drawings, wordless street signs, silhouettes, pictures from magazine, ink blots, postcard pictures, wordless picture books, stamps, and X-rays.

3. Authentic printed materials: newspaper articles, movie advertisements, astrology columns, sports reports, obituary columns, advice columns, lyrics to songs, restaurant menus, street signs, cereal boxes, candy wrappers, tourist information brochures, university catalogs, telephone books, maps, TV guides, comic books, greeting cards, grocery coupons, pins with messages, and bus schedules.

\section{BENEFITS OF AUTHENTIC MATERIALS}

There is a general agreement among foreign/second language instructors that authentic language input can be utilized in second language learning. According to scholars (Gilmore, 2007; Martinez, 2002; Nunan, 1999; among others), there are many advantages associated with authentic language materials which make these materials pedagogically valuable sources of great amount of exposure to the target language.

With regards to this, Martinez (2002) provided a number of sound advantages for incorporating authentic language materials for language teaching. An initial advantage is that authentic language materials provide a wide range of language change of the target language. For example, through listening to authentic songs and stories in the target language, language learners will be able to hear dialectal differences of various countries that speak the target language (Martinez, 2002). These dialectal variations from one target language speaking country to the next can be used for a class discussion. Brinton (1991) underscored the point that authentic materials from media can reinforce the direct relationship between the language classroom and the outside world for the students.

Melvin and Stout (1987) found an overall increased motivation to learn in the students when they use authentic language materials for the study of culture. As the language learners gained more confidence working directly with authentic materials, they also reported an increased understanding of the practical benefits of being able to use the language in real world scenarios. They went on to state that authentic language 
input would be helpful for language learners to practice skills they might need outside the classroom and learn about cultures on their own. In relation to the motivating aspect of authentic materials, Nunan (1999) and Gilmore (2007) acknowledged that it is essential for language learners to have exposure to various kinds of authentic language material because it helps to motivate them by bringing the content and the subject matter to life. Moreover, it enables them to make the important connections between the classroom world and the real world outside the classroom setting.

Tamo (2009) also found that in using authentic materials in the classroom is significant for many reasons. Some of them are: a)students are exposed to real discourse, as in videos of interviews with famous people where intermediate students listen for gist. They provide exposure to real language, $b$ ) authentic materials have a positive effect on learner motivation, c) authentic materials keep students informed about what is happening in the world, so they have an intrinsic educational value. As teachers, we are educators working within the school system, so education and general development are part of our responsibilities, d) textbooks often do not include incidental or improper English, e) authentic materials can produce a sense of achievement.

However, there are disadvantages to using authentic materials in their raw form without adaptation or support. Some of them are: a) authentic materials may be too culturally biased or too difficult to understand outside the language community thereby making them inaccessible to beginners or elementary learners, b) authentic materials may contain items, particularly vocabulary, which are of low frequency and of peripheral use to the learner and may never be encountered again, c) authentic targetlanguage materials are not readily available, obtaining them can be time consuming and frustrating.

\section{SELECTING AND USING AUTHENTIC MATERIALS}

In selecting authentic materials used in EFL classroom, the teacher must consider and exploit the materials to maximise their benefit to students. According to Robert (2012), some considerations in selecting the authentic materials are: (a) relevance and interest, (b) cultural appropriateness, (c) linguistic and cognitive demands of the text, and (d) practical considerations.

Meanwhile, Thompson (1997) and Cook (1981) also proposed that there are some points to be considered in selecting authentic materials. The points are interest, background knowledge, language, and text organization. Materials for audio and video need special considerations for the quality of sound, number of speakers, topic, duration, and also supporting visual.

Furthermore,Bureau of Educational and Cultural Affairs, U.S. Department of State provides some guidelines for choosing authentic materials (2010). The materials are appropriate for the learner age group in terms of interest and level of language proficiency. The materials contain examples of the point of the lesson, illustrating authentic use of the language points. The materials are in a style of English learners are most likely to hear and use. For example, listening texts can include any of the various forms of native speaker English and/or examples of native and non-native English that are likely to be used in the learners' environment. Materials are available locally, on the Internet, or have been collected by the teacher. The materials are of good quality, whether print, sound, pictures, or other graphics. The materials can be used in the classroom for authentic-like tasks or activities. 
Meanwhile, in using authentic materials, for the basic principles of receptive skill lesson development, the teacher should consider to not necessarily simplify the text, but simplify the tasks and then design a hierarchy of tasks for pre-activities, global activities, specific information activities, linguistic activities, and post activities (Thompson, 1997).

In addition, the teacher should not 'mutilate' the text and willfully simplify it to the extent that the language is no longer authentic. Instead, learners should be taught strategies of how to deal with authentic texts and understanding the gist of such texts, e.g. by inferring the meaning of unknown words using the context or knowledge of their mother tongue (if the words are similar). This guideline again implies that the choice of textbooks is of extreme importance to ensure that learners do not learn using texts that are outdated and no longer of relevance in today's world.

As for the authentic materials have many advantages compared to inauthentic materials, however, it does not mean that choosing and using appropriate authentic materials in EFL class can really improve students communicative competence. The most important thing is what kinds of methods are adapted to utilize these materials. As for the question of utilizing, different people have different opinions.

According to many researchers the following ways of using authentic materials are effective.

\section{A. Integrating Target Culture with Language Teaching}

Language and culture are closely related with each other. Language is a part of culture and plays an important role in it. On one hand, without language, culture cannot be transmitted. On the other hand, language is influenced and shaped by culture. Language and culture interact with each other and the understanding of one influences the understanding of the other.

In the teaching of English as foreign language, we can find that the materials, especially authentic materials, often have much cultural content that is closely related to the knowledge of American and British culture, society, and economy. If students lack this kind of knowledge, there will be difficulties in their ability. Maybe many of us have this experience: when we are listening or reading to something familiar to us, whatever is concerned, we usually find it easy to understand. Even if there are some new words, we are able to guess their meanings from the context. However, if the materials are unfamiliar to us, or too culturally based, we may feel very difficult. Even if there are no new words in the materials, we can only get the literal meaning. We do not understand the meaning in depth, because of the lack of cultural information. For instance, here is a sentence from a report, "The path to November is uphill all the way." November literally means "the eleventh month of the year". But here it refers to the presidential election to be held in November. Another example is "red-letter-days" which is a simple phrase and easy to hear, meaning holidays such as Christmas and other special days. Without teachers' explanation, students are usually unable to understand them. In order to solve the problems in this respect, teachers are suggested to pay attention to culture teaching in class. The ways to introduce such barriers can be as follows: 


\section{Introducing background knowledge}

Some authentic materials are too culturally based, thus not easy for students to understand. It is better for teachers to introduce some background information before starting the class activities. For example, if what the students are going to discuss is a piece of BBC or VOA news, the teacher had better explain the names of countries, places, people's names and ages etc. appeared in the news, which are a little difficult for second language learners. If the materials are on western customs, the possible way for the teacher is to ask students to search the relevant information in advance and then share what they have found with the whole class. If teachers prepare original English films for students, so it is wise for them to introduce the characters, the settings, and the general plot and tell students how to watch these original films. In this way, students may feel easier to understand the authentic listening materials.

\section{Explaining idioms}

Idioms are important in any language and culture. They are often hard to understand and hard to use appropriately. It is usually impossible to understand them without the context. Some English idioms have meanings much far more than the literal meanings. Authentic materials are likely to contain many idioms, especially in films. The teacher should explain the idioms and ask students to accumulate them. Students can benefit from this in the long run.

\section{Encouraging students' self-learning}

Time in class is limited. Teachers' teaching is just one of the learning resources for the students. Teachers should raise students' cultural awareness, and encourage them to learn the target culture by themselves. Here is a long term plan of culture learning: the teacher asks the students to learn the target culture in their spare time in group. Students are supposed to have discussions on their interested topics with their group members and prepare a report for the whole class. In this way, they can accumulate their information and learn more. It is also better for the teacher to give the students one hour to report each week. This plan emphasizes students' self-learning.

Teacher can follow this suggested procedure to enhance students' self-learning:

1. Divide the whole class into groups.

2. The teacher provides topics for each group. Instead, students are allowed to find their own topics if they like. Then they are expected to search as much information as possible on the selected topic. After this, they should hold a discussion with their group members on the found information and decide how and who will give the report.

3. On the "report day", the representatives of each group give their reports one by one. Instead of reading the report, they are asked to retell what they have prepared. The rest of the students should regard this class as a practice and respond to it after the report.

4. When the reporter finishes, students can ask whatever questions related to the report. If the reporter can not give the answers, he/she can turn to his/her group members.

Students may benefit on this plan. Every student is getting involved in this process, so they are highly motivated and willing to listen or participate to each other very carefully. Then, in the preparing process, students may read quite an amount of 
cultural information, and deal with various authentic materials. Their knowledge on culture will soon be enriched. Day by day, when they come back in EFL class, they may find that the authentic materials are no longer so difficult, and when they go outside the classroom, they may find it easier to communicate with native speakers.

\section{B. Helping students to adapt to authentic situation}

Successfully utilizing a continuing series of authentic materials in English language learning classroom is simply a matter of adapting those materials to suit the needs of the language learners. According to Lombardi (2007), there are 10 design elements providing teachers with a useful checklist that can be adapted to any subject matter domain of authentic materials.

1. Real-world relevance: Authentic activities match the real world tasks of professionals in practice as nearly as possible. Learning rises to the level of authenticity when it asks students to work actively with abstract concepts, facts, and formulae inside a realistic and highly social — context mimicking "the ordinary practices of the disciplinary culture."

2. Ill-defined problem: Challenges cannot be solved easily by the application of an existing algorithm; instead, authentic activities are relatively undefined and open to multiple interpretations, requiring students to identify for themselves the tasks and subtasks needed to complete the major task.

3. Sustained investigation: Problems cannot be solved in a matter of minutes or even hours. Instead, authentic activities comprise complex tasks to be investigated by students over a sustained period of time, requiring significant investment of time and intellectual resources.

4. Multiple sources and perspectives: Learners are not given a list of resources. Authentic activities provide the opportunity for students to examine the task from a variety of theoretical and practical perspectives, using a variety of resources, and requires students to distinguish relevant from irrelevant information in the process.

5. Collaboration: Success is not achievable by an individual learner working alone. Authentic activities make collaboration integral to the task, both within the course and in the real world.

6. Reflection (metacognition): Authentic activities enable learners to make choices and reflect on their learning, both individually and as a team or community.

7. Interdisciplinary perspective: Relevance is not confined to a single domain or subject matter specialization. Instead, authentic activities have consequences that extend beyond a particular discipline, encouraging students to adopt diverse roles and think in interdisciplinary terms.

8. Integrated assessment: Assessment is not merely summative in authentic activities but is woven seamlessly into the major task in a manner that reflects real-world evaluation processes.

9. Polished products: Conclusions are not merely exercises or substeps in preparation for something else. Authentic activities culminate in the creation of a whole product, valuable in its own right.

10. Multiple interpretations and outcomes: Rather than yielding a single correct answer obtained by the application of rules and procedures, authentic activities allow for diverse interpretations and competing solutions. 


\section{TEACHER'S AND STUDENTS' ROLES}

Teacher roles have changed and proceed to meet new requirements. The most successful English as a foreign language (EFL) teaching programs, however, should involve the whole learner in the experience of language as a network of relations between people, things, and events (Chen, 2005). Then, The role of the teacher and the learners is very crucial in the teaching and learning environment. The teacher becomes a facilitator of his students' learning. The teacher is a manager in classroom activities (Hossen, 2008). Classroom activities should be directed to promote communication; such as advising students, answering students' questions and monitoring their performance but sometimes the teacher is also a co-comunicator who engage in communicative activity along with the students/learners.

Moreover, the teacher establishes situation that prompt communication between and among the students. It can be in pairs, triads, small groups and whole group. Teachers give students an opportunity to express their individuality by having them share their ideas and opinions. A teacher evaluates not only his students' accuracy, but also their fluency.

Meanwhile, Al-Fallay (2007) found that the students in using authentic materials through communicative language teaching play crucial roles as communicators in which they are actively engaged in negotiating meaning, in trying to make themselves understood, and in understanding others even when their knowledge of the target lan $\neg$ guage is incomplete. And since the teacher's role is less dominant than in a teacher-cen $\neg$ tered method, students are seen as more responsible managers of their own learning.

From the roles of each party plays, it develops students' competence because it focuses on both form and function (Chang, 2011). From this point, teacher as a facilitator develops communicative competence integrated with grammar skills. For students, linguistic form and communicative function are important because grammar serves as a basis for communication to take place efficiently.

\section{CONCLUSION}

By using authentic materials, students involve in the real language as long as teachers provide them with educational support. The authentic materials should be used in accordance with the students' level of knowledge and the students should be helped by their teachers to overcome the difficulties they encounter. The use of authentic materials appropriately can advance students' communicative competence.

\section{REFERENCES}

Acar, Ahmet. (2005) The "Communicative Competence" Controversy. Asian EFL Journal. http://www.asian-efl-journal.com/sept_05_ac.pdf accessed on October 20, 2013.

Al-Fallay, Ibrahim S.M. (2007). Communicative Language Teaching. http://faculty.ksu.edu.sa/fallay/Pages/ChapterNineCommunicativeLanguageTea ching.aspx accessed on October 25, 2013.

Bahrani, Taher and Tam Shu Sim. (2012). Audiovisual News, Cartoons, and Films as Sources of Authentic Language Input and Language Proficiency Enhancement. 
TOJET: The Turkish Online Journal of Educational Technology - October 2012, volume 11 Issue 4.

Brinton, D.M. (1991). The use of media in language teaching. In M.Celce-Murcia (ed.), Teaching English as a Second or Foreign Language, Boston: Heinle and Heinle Publishers.

Bureau of Educational and Cultural Affairs. U.S. Department of State.(2010). Shaping the Way We Teach English. Module 8: Authentic Materials. http://americanenglish.state.gov/resources/shaping-way-we-teach-englishsuccessful-practices-around-world, accessed on December 10, 2013.

Canale, M., \& Swain, M. (1980). Theoretical bases of communicative approaches to second language teaching and testing. Applied Linguistics, 1, 1-47.

Celce-Murci, Marianne \& Elite Olshtain. (2005). Discourse-Based Approaches: A new Framework. For Second Language Teaching and Learning in Handbook of Research in Second Language Teaching and Learning edited by Eli Hinkel.Lawrence Erlbaum Associates Publisher, New Jersey.

Celce-Murcia, Marianne and Zoltan Dornye. (1995). Communicative Competence : A Pedagogically Motivated Model with Content Specifications issues in Applied Linguistics ISSN 1050-4273, Vol. 6 No.2 1995 page 5-35. Regents of the University of California http://www.zoltandornyei.co.uk/uploads/1995-celcemurcia-dornyei-thurrell-ial.pdf accessed on October 26, 2013.

Chang, Ming. (2011). EFL Teachers' Attitudes toward Communicative Language Teaching in Taiwanese College. Asian EFL Journal Professional Teaching Articles Volume 53 July 2011. www.asian-efl-journal.com/PTA/Volume-53mc.pdf accessed on October 20, 2013.

Cook, Vivian. (1981). Using Authentic Materials in the Classroom. http://homepage.ntlworld.com/vivian.c/Writings/Papers/AuthMat81.htm, accessed on December 10, 2013.

Gebhard, J.G. (1996). Teaching English as a foreign language: A teacher selfdevelopment and methodology. Ann arbor: the university of Michigan press.

Gilmore, A.(2004). A comparison of textbook and authentic interactions. ELT Journal, $58(4)$.

Harmer, J. (1991). The Practice of English Language Teaching. London: Longman.

Hossen, Mohammad Toffazal. (2008). Communicative Language Teaching: Teacher Perception In Bangladesh (Secondary Level). Department of English and Humanities. BRAC University. Dhaka. Bangladesh. http://dspace.bracu.ac.bd/bitstream/handle/10361/92/Communicative\%20langu age\%20teaching.PDF? sequence $=1$ accessed on October 27, 2013. 
Hymes, D. (1972). On Communicative Competence, in P ride, J. and Holmes,J.(eds.), Sociolinguistics. England: Penguin Hardmonsworth.

Lombardi, Marilyn M. (2007). Authentic Learning for the 21 st Century: An Overview. Edited by Diana G. Oblinger ELI Paper 1: 2007. Educause Learning Initiative.

M.L. Chen. (2005). The effect of the cooperative learning approach on Taiwanese ESL students' motivation, English listening, reading and speaking competences, Unpublished Doctoral Dissertation. La Sierra University, California, Retrieved February 12, 2008, from http://proquest.umi.com

Martinez, A.G. (2002). Authentic Materials: An Overview on Karen's Linguistic Issues -http://www3.telus.net/linguisticsissues/authenticmaterials.html. Accessed on November 8, 2013

Melvin, B.S. and Stout, D.S. (1987). Motivating language learners through authentic materials. In W. Rivers (ed.) Interactive Lan-guage Teaching . New York: Cambridge University Press, 44-56

Moss, Donna. (2005). Teaching for Communicative Competence. Interaction in the ESOL Classroom. Focus on Basics. Connecting Research \& Practice. Volume 7, Issue C, March 2005. http://www.ncsall.net/fileadmin/resources/fob/2005/fob_7c.pdf, accessed on October 26, 2013.

Nunan, D. (1999). Second Language Teaching and Learning. Boston: Heinle and Heinle Publishers.

Oxford University Press ELT. (2011). How ESL and EFL classrooms differ. http://oupeltglobalblog.com/2011/07/12/how-esl-and-efl-classrooms-differ/ accessed on October 20, 2013

Pietila, Katri. (2009). Bringing real life English into foreign language classrooms: Language learners' views on the use of authentic and artificial materials in the English language learning classrooms. Thesis. University of Jyvaskyla. Department of Languages. English. Pp 363-374.

Richards, J. C. (2001). Postscript: the ideology of TESOL. In Carter, R. \& Nunan, D. (Eds). The Cambridge guide to teaching English to speakers of other languages. Cambridge: Cambridge University Press.

Robert, Rachael. (2012). Tips on selecting effective authentic reading materials. http://elt-resourceful.com, accessed on December 10, 2013

Sanderson, P. (1999). Using Newspapers in the Classroom. Cambridge: Cambridge University Press.

Shomoossi, N. \& Ketabi, . (2007). A critical look at the concept of authenticity. Electronic Journal of Foreign Language Teaching. 4(1). Pp 149-155. 
Tamo, D. (2009). The Use of Authentic Materials in Classrooms. Article 9 in LCPJ, volume 2.http://www.lcpj.pro/skedaret/127754768574_pdfsam_LCPJ,\%20Per\%20shtyp.pdf accessed on November 8, 2013

Thompson, Chantal. (1997). Selecting Authentic Materials (Reading, Listening, Viewing). The ACTFL Annual Meeting. Nashville. https://facultystaff.richmond.edu/ rterry/Middlebury/authentic.htm, accessed on December 11, 2013.

Widdowson, H.G. (1990). Aspects of Language Teaching. Oxford: Oxford University Press. 